\title{
ACCURACY VERIFICATION OF PROCESSING METHODOLOGY IN PARTICLE IMAGE VELOCIMETRY FOR FLOW AROUND BUILDING
}

\author{
建物周辺気流を対象とした粒子画像流速測定法における解析手法の精度検証 \\ Hisashi KOTANI*1 and Tomohiro KOBAYASHI*2 \\ 甲谷寿史，小林知広
}

Particle Image Velocimetry (PIV) is beneficial means to obtain velocity distribution for both fundamental and applied work in architectural-environment research field, because it enables simultaneous measurement without any contact of devices to the flow. There exist a number of factors that can affect result. It is roughly divided into two types, one is image quality, and the other is analysing method. This paper focuses on effect of several processing parameters in PIV on its accuracy, and mainly investigates cross-correlation algorithm, interrogation window size, and the number of iteration in recursive processing. The objective of this work is to understand an impact of each parameter setting for a highly turbulent and shear flow because it has almost never been shown systematically. As analysis target, the flow around a cross-ventilated room model was adopted. By conducting a parametric study combining above-shown parameters, accuracy of analysed velocity and wind direction is finally studied.

Keywords : $\quad$ PIV, Direct Cross-Correlation Method, FFT Cross-Correlation Method, Recursive correlation Method, Wind Tunnel Test PIV，直接相互相関法，FFT 相互相関法，再帰的相関法，風洞実験

\section{Introduction}

Since a frame-to-frame tracer cross-correlation method of particle image velocimetry (PIV) was first introduced in 1980 's ${ }^{1-3)}$, it has rapidly been improved ${ }^{4)}$ ${ }^{5)}$ and many advanced algorithms have been proposed afterwards. For instance, FFT cross-correlation technique ${ }^{6)}$ played an important part in progress of PIV use because it could reduce computational load significantly. Keane and Adrian ${ }^{7}$ introduced a concept of "super resolution PIV", and Hart ${ }^{8)}$ also showed the recursive processing algorithm which improved spatial resolution without losing statistical reliability through recursive processing. To improve accuracy, as a recent work, Wieneke and Pfeiffer ${ }^{9)}$ has showed an adaptive PIV algorithm which calculates the optimal local interrogation window size and shape based on flow gradients and correlation value. It was shown that this method was effective especially for shear flow. Although the FFT cross-correlation method has mainly been used in many years, the direct cross-correlation method has come to be used because of development of the Graphics Processing Unit (GPU) in recent years.

Due to the dramatic progress of computational performance in these last few decades, a number of commercial codes have been spread, and they have now often been used for both fundamental and applied research purpose. Above-mentioned PIV processing techniques were developed as general methods ${ }^{10)}$. They are widely adopted as "options" in many commercial PIV codes at the present time. Owing to its advantages, e.g. simultaneous and contactless $2 \mathrm{D}$ flow measurement, PIV technique began to be commonly used in the field of the mechanical engineering. In the architectural environmental research field, many works came to be seen from the early 2000's. Yamanaka et al ${ }^{11)}$ showed instantaneous velocity field around a single-sided opening of a room model using PIV. Zhu and Kato et al. ${ }^{12}$ used PIV technique for an analysis of the local flow pattern around an occupant. Nakajima, Ibaraki, and Kondo ${ }^{13)}$ investigated the airflow characteristics around supply air terminal in a full-scale test room. Akabayashi et al. ${ }^{14)}$ applied PIV measurement in understanding characteristics of the fluctuating airflow. The authors ${ }^{15-18)}$ also conducted PIV measurement in analysing cross-ventilation flow inside/outside a room model by wind tunnel test.

The result obtained from PIV measurement may vary depending on many factors regarding experimental setting or calculation parameter. Kondo and Nakajima ${ }^{19)}$ proposed a method to eliminate spurious vector by introducing permissible range of spatial shift detection based on an idea of recursive correlation algorithm. Akabayashi et al. ${ }^{20)}$ showed the effect of seeding method on accuracy. The findings obtained from their works are believed to be helpful in planning

This article collects and recomposes the outcomes presented in the published AIJ conference papers ${ }^{21}$.

*1 Assoc. Prof., Divison of Global Architecture, Graduate School of Engineering, Osaka University, Dr.Eng.

* 2 Lect., Department of Urban Engineering, Graduate School of Engineering. Osaka City University, Dr.Eng.

\section{大阪大学大学院工学研究科地球総合工学専攻} 准教授・博士 (工学)

大阪市立大学大学院工学研究科都市系専攻 講師 ·博士 (工学) 
PIV experiment. Given that commercial codes are now usually used, it seems also useful to show the effect of processing parameter on accuracy of PIV result. To the best of authors' knowledge, however, few works can be seen that have shown accuracy of PIV combining each parameter setting. Therefore, this paper aims to clarify the impact of PIV processing parameters on accuracy more or less systematically. Since the use of direct cross-correlation method has been increased, as mentioned above, this paper first focuses on PIV processing algorithm, i.e. difference in accuracy between FFT and direct cross-correlation method. Second, the effect of interrogation window size is studied because it is considered to be important parameter which affects result, especially for turbulent shear flows. Third, in connection with interrogation window size, number of iteration in recursive correlation analysis is studied, because it has not been fully understood, especially for highly turbulent flow in this research field.

Thus, the main purpose of this paper is how the result of PIV measurement changes. However, it must be noted that this paper does not show uncertainty of PIV but only focuses on accuracy. Based on PIV measurement conducted in the authors' previous work, in this paper, accuracy of PIV analysis is investigated by conducting a parametric study combining parameter settings of 1) FFT/direct correlation algorithm, 2) interrogation window size, and 3 ) number of iteration for recursive correlation, to present technical findings in using PIV.

\section{Outline of Preceding PIV Measurement}

\subsection{Visualization in the Wind Tunnel Test}

In the authors' previous work ${ }^{16)}$, wind tunnel experiment and CFD analysis were conducted for cross-ventilation flow field outside a test model which was made of acrylic board shown in Fig. 1. The aspect ratio of the test model configuration was $384 \mathrm{~mm}$ (W) : 181.6 mm (D), i.e. 2.11:1. Throughout this paper, we shall adopt dimensionless coordinate based on reference length $\mathrm{D}=181.6 \mathrm{~mm}$. The test model was assumed to include nine one-room residences, and only the openings on both windward/leeward sides provided for the central room were open. In the wind tunnel experiment, PIV and five-hole pitot tube was adopted as experimental device. The test model was originally made with intent to analyse flow both inside and outside the room, but these two kinds of measurement were conducted in analysing external flow. In order to verify accuracy of PIV, this paper only focuses on outside of the model. Although side length of the openings $\mathrm{L}$ was varied in that work, this paper focuses on one case of $\mathrm{L}=45 \mathrm{~mm}$ and a parametric analysis regarding PIV processing setting is done by using the visualized flow images obtained in that work. This chapter explains the outline of the experiment where PIV images were obtained. For more details, see Kobayashi et $\mathrm{al}^{16)}$.

The test model was located at the centre of the tunnel and exposed to a free flow of $10 \mathrm{~m} / \mathrm{s}$. The wind direction was perpendicular to openings. As illustrated in Fig. 2, the airflow inside/outside the model was visualized in the PIV measurement. A smoke generator (Kanomax Japan, 8304) was located outside of the wind tunnel, and the tracer was injected into the wind tunnel. A double pulse Nd:YAG laser (New Wave Research, DPIV-N50) was used and the laser sheet was oriented horizontally through a window of the wind tunnel, the flow was captured by a CCD camera. A couple of visualized-flow images were captured with time interval of $200 \mu \mathrm{s}(\Delta \mathrm{t})$ at every 0.25 seconds, and the same procedure was repeated 100 times. Table 1 summarizes the experimental condition to obtain PIV images. The camera and the laser were controlled by PIV program (La Vision, Davis 7.2 ). The size of experimental plane was $625 \mathrm{~mm} \times 471 \mathrm{~mm}$ and obtained image for this plane had a resolution of 1,376 pixels $\times 1040$ pixels, i.e. 2.2 [pixel/mm]. This indicates that the model depth $\mathrm{D}$ was divided into 400 pixels. Considering double pulse laser interval $(\Delta \mathrm{t}=200 \mu \mathrm{s}), 10 \mathrm{~m} / \mathrm{s}$ of approaching flow velocity indicates 4.22 [pixel/ $\Delta \mathrm{t}$. This approaching velocity can also be expressed as $0.01056[\mathrm{D} / \Delta \mathrm{t}]$ by using reference length $\mathrm{D}$. The velocity distribution was obtained on two planes separately as shown in Fig. 3 .

\subsection{Obtained Image and PIV in the Previous Work}

In the authors' previous work, these images have been analysed by FFT crosscorrelation method with recursive calculation. Table 2 gives the PIV parameter adopted in that work. Here, both sub-pixel interpolation and sub-pixel shift were applied to improve precision and to avoid peak locking respectively. Fig. 4 shows

Table 1 Experimental Condition for PIV Measurement

\begin{tabular}{|c|c|}
\hline Camera Frame Size & $\begin{array}{c}625 \mathrm{~mm} \times 471 \mathrm{~mm} \\
1,376 \text { pixel } \times 1,040 \text { pixel } \\
(2.2 \mathrm{pixel} / \mathrm{mm})\end{array}$ \\
\hline Controling/Analysing Program & Davis 7.2 \\
\hline Time Interval of Pulse & $200 \mu \mathrm{s}$ \\
\hline Sampling Frequency & $4.0 \mathrm{~Hz}$ \\
\hline Sampling Time & 25 seconds \\
\hline Laser Output & $50 \mathrm{~mJ} /$ Pulse \\
\hline Seeding Size & $0.3-1.0 \mu \mathrm{m}$ \\
\hline \multicolumn{2}{|c|}{ Table 2 Parameters for PIV Analysis in the previous work } \\
\hline Program & Davis 7.2 \\
\hline Algorithm & $\begin{array}{l}\text { FFT Cross-Correlation Method } \\
\text { (Recursive Correlation Method) }\end{array}$ \\
\hline $\begin{array}{l}\text { Interrogation } \\
\text { Window Size }\end{array}$ & $\begin{array}{l}\text { Pass } 1: 64 \text { pixel } \times 64 \text { pixel } \\
\text { Pass } 2: 32 \text { pixel } \times 32 \text { pixel } \\
\text { Pass } 3: 32 \text { pixel } \times 32 \text { pixel }\end{array}$ \\
\hline Overlap & $50 \%$ \\
\hline Total Numver of Vectors & $5,590(86 \times 65)$ \\
\hline
\end{tabular}

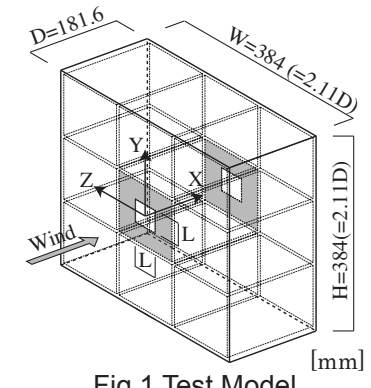

Fig.1 Test Model

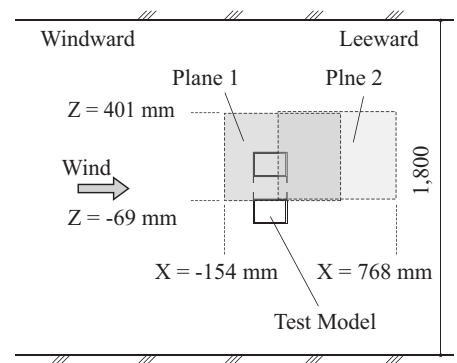

Fig.3 Analysed Region by PIV

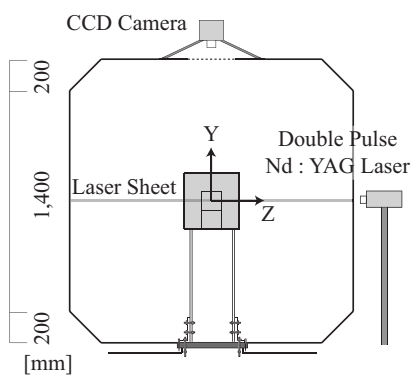

(2) YZ Cross-section

(1) XY Cross-section

Fig.2 Experimental Set-up of PIV Measurement 
velocity vector plots obtained from PIV based on above-mentioned setting and CFD using Standard k- $\varepsilon$ model and Large Eddy Simulation, where PIV vectors were omitted to be $1 / 16$ of total. It looks qualitatively good results, and well agrees with that of LES. However, it is questionable that PIV result can always be regarded as true value. That is because, there exist many factors which cause difference in PIV results. Calculation parameter can have quite significant effect as well as image quality. i.e. Even when obtained result is locally incorrect, there might be possibility to improve it only by changing the way to detect peak correlation. This is the focus of this paper, and the authors aim to understand how significant the effect of major calculation parameter is, especially crosscorrelation algorithm, interrogation size, and the number of iterations for recursive correlation procedure.

Fig. 5 (1) shows an extract from the obtained images for first frame, and (2) is enlarged images around windward corner of which size is 160 pixels by 128 pixels, and (3) shows the corresponding instantaneous velocity vector plots on measurement plane 1 without vector omission. Here, Z' indicates the horizontal distance from the windward corner in $\mathrm{Z}$ direction. Despite that the quality of image was not particularly high in terms of variation of tracer concentration, e.g. tracer distribution was not good enough around the windward corner due to flow separation, it seemed that the instantaneous velocity obtained was qualitatively good. In Fig. 6, for more quantitative discussion, obtained time-averaged velocity distributions along three lines in $\mathrm{Z}$ direction are compared with those from measurement by five-hole pitot tube and LES. Here, all velocities are divided by $10 \mathrm{~m} / \mathrm{s}$ which is the approaching wind speed ${ }^{* 1)}$. Regarding lines of $\mathrm{X}=60 \mathrm{~mm}$ and $120 \mathrm{~mm}$, all three methods show similar tendency. Nevertheless, velocity obtained from PIV is obviously underestimated. Along the line of $\mathrm{X}=0 \mathrm{~mm}$ also, PIV result shows smaller velocity, and shows different distribution around the corner. It is believed that LES and the five-hole pitot tube show correct tendency because flow is accelerated due to the contraction caused by flow separation. In the area between $Z^{\prime}=0$ and 10 mm, it seems difficult to detect correct vector because the side wall is overlapped with visualized flow due to perspective view. This of course can be a problem, and if needed, it is possible to be avoided by location of the camera (For example, see Akabayashi et al. ${ }^{14)}$ ). However, even in the outside of such an area (Z'>10 mm), it is apparent that PIV underestimates velocity. This might be due to image quality, but it can also be possible to improve these results by only changing PIV processing parameter. Focusing on the latter possibility, the parameters regarding PIV processing are varied and their sensitivity is discussed in the next chapter.
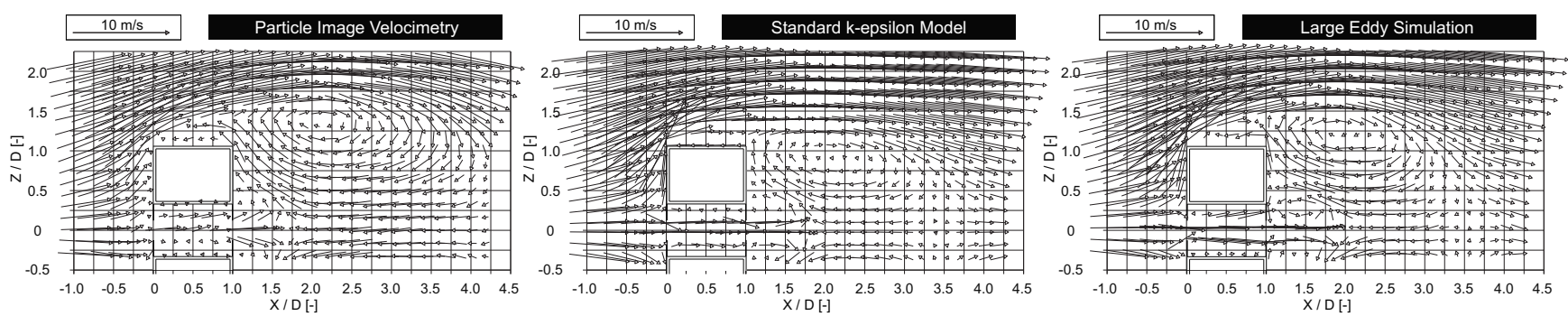

Fig. 4 Velocity Vectors obtained from PIV and CFD (Kobayashi et al. ${ }^{16)}$ )

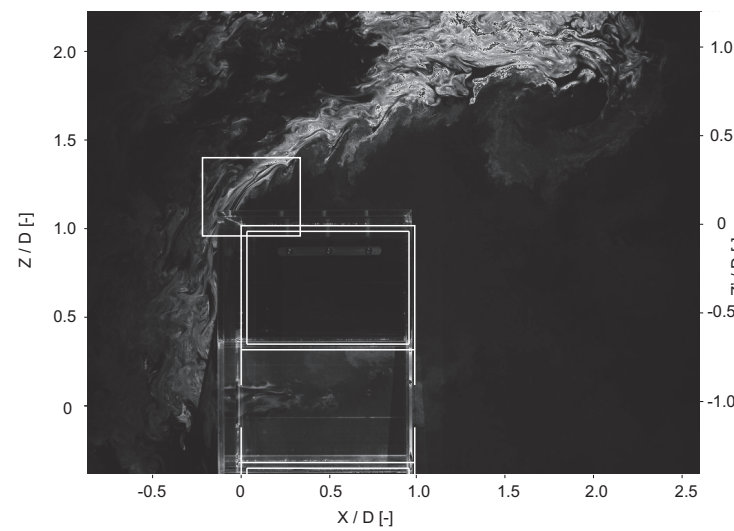

(1) Whole image for Plane 1 in Fig. 3 (Frame 1) (Squared area indicates the enlarged region in (2))

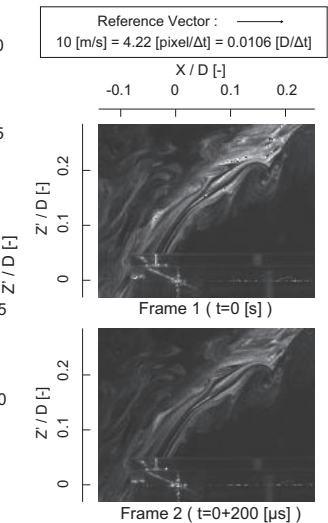

(2) Enlarged image around windward corner for each frame

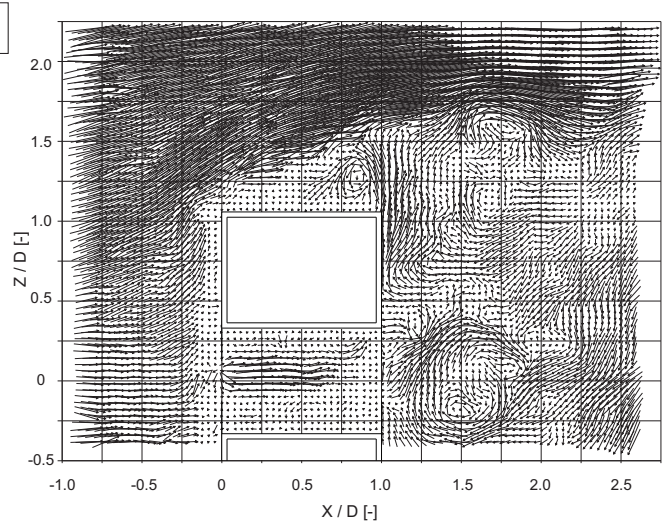

(3) Instantaneous velocity vector field for Area 1 in Fig. 3

Fig. 5 Extracted example obtained image and velcoity vector field for the case of $L=45$ deg.

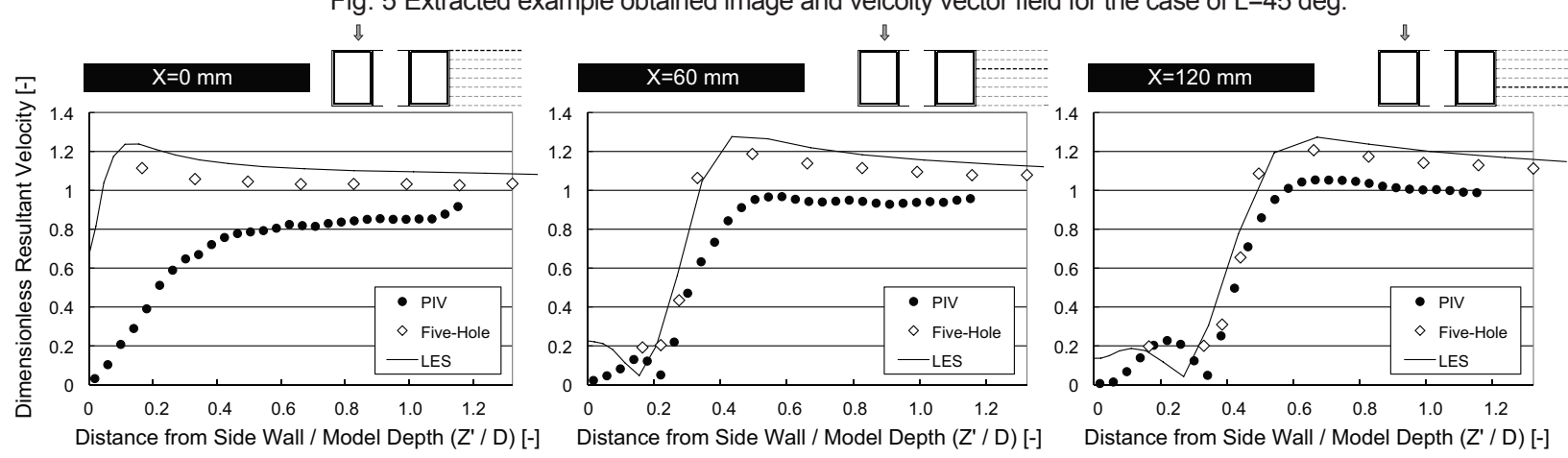

Fig. 6 Velocity distribution in $Z$ direction along lines of $X=0,60,120 \mathrm{~mm}$ obtained from PIV, LES, and Five hole pitot tube in the previous work 


\section{Parametric Study regarding PIV Processing}

\subsection{Studied Cases}

By using flow images obtained in the wind tunnel experiment described in the previous chapter, effect of three PIV processing parameter is studied as mentioned above, i.e. 1) algorithm to obtain cross-correlation, 2) interrogation window size, and 3) number of iteration in recursive correlation method. For all cases, both FFT and direct cross-correlation method were applied. Four cases of interrogation window size were studied, i.e. $8 \times 8,12 \times 12,16 \times 16$, and 32 $\times 32$ pixels. Both recursive and single pass processing were performed for all cases of interrogation window size. When interrogation window size was varied with recursive processing, number of iterations (hereinafter expressed as "pass") was fixed to be 20 . In order to test the iteration performance, the number of recursive processing was also varied as 1, 2, 5, 10 and 20 passes. For all analyses with recursive processing, 1 pass was added with double interrogation window before main calculation. Table 3 summarizes all cases analysed in this parametric study. A commercial PIV code Davis 8.0 (LaVision) was used for all cases. Overlapping of interrogation windows was not regarded as parameter and fixed to be $50 \%$ for all analyses, because this could not affect accuracy but only increase total number of vectors. Given the scale of $2.2 \mathrm{pixel} / \mathrm{mm}$ shown in Table 2, spatial shift of tracer during $200 \mu$ s is supposed to be 4.4 pixels where airflow velocity is $10 \mathrm{~m} / \mathrm{s}$. Since the direct cross-correlation processing should be performed on an assumption that maximum shift of discrete window is to be sufficiently large, it is basically fixed to be 8 pixels. However, maximum shift of 4 pixels was given for the case of $8 \times 8$ pixels interrogation window, because it should not be less than half of interrogation window size ${ }^{10}$. As for the calculation time, the calculation time of FFT cross-correlation method is generally shorter than direct cross-correlation method. However PIV code used in this study showed the opposite tendencies because of the software specification. This code uses Central Processing Unit (CPU) with GPU always when the direct cross-correlation method is used. If FFT cross-correlation method is used, this code uses only CPU. Thus, direct cross-correlation method has a shorter calculation time dramatically due to GPU. For instance, in the case of $8 \times 8$ pixels interrogation window with 20 recursive processing as the maximum calculation load, the calculation times are 102 seconds by direct cross-correlation method and 4691 seconds by FFT cross-correlation method. As the minimum calculation load, the case of $32 \times 32$ pixels interrogation window with no recursive processing (single pass processing), they are 15 seconds by direct cross-correlation method and 33 seconds by FFT. These calculations were conducted by Personal Computer with Intel Xeon 2.67GHz × 2 CPU and GPU of NDVIA GeForce GTX760 × 1 unit (1,152 cores).

\subsection{Two-Dimensional Velocity Distribution}

In order to understand the effect of processing algorithm and recursive analysis qualitatively, distributions of time-averaged velocity resultant are compared among four typical cases in Fig. 7. Velocity from the PIV in the previous work is also shown in Fig. 8 just for reference. In general, quite low velocity is seen in the vicinity of side and windward wall. This area corresponds to perspective image of side and front view, and it cannot be improved as long as the same images are used. Comparing with Fig. 8, all results in Fig. 7 show relatively large spatial variation due to smaller interrogation window size. As for the effect of parameter studied, direct cross-correlation method resulted in more "sharp" velocity distribution around the separation corner. This indicates that FFT crosscorrelation method cannot evaluate velocity where velocity gradient is large if compared with direct cross-correlation method.

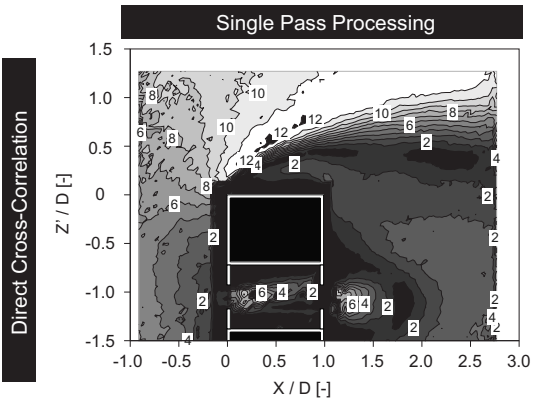

(3) 16 pixel $\times 16$ pixel $\times 1$ pass

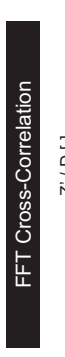

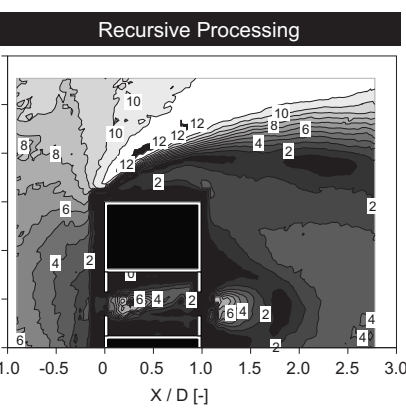

32 pixel $\times 32$ pixel $\times 1$ pass 16 pixel $\times 16$ pixel $\times 20$ pass

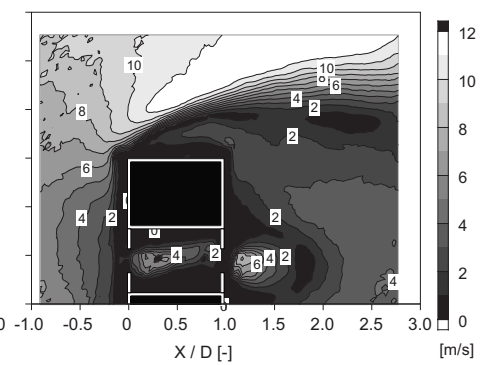

(2) 32 pixel $\times 32$ pixel $\times 1$ pass

(1) 16 pixel $\times 16$ pixel $\times 1$ pass

Fig. 7 Average Velocity distribution obtained from single and 20-pass PIV processing ( Top : Direct cross-correlation method, Bottom : FFT cross-correlation method)

\section{Table 3 PIV Processing Parameter Setting}

\begin{tabular}{|c|c|c|c|c|c|c|}
\hline Algorithm & \multicolumn{3}{|c|}{$\begin{array}{l}\text { FFT Cross-Correlation Method } \\
\text { Direct Cross-Correlation Method }\end{array}$} & \multicolumn{3}{|c|}{$\begin{array}{l}\text { (Both method were applied for } \\
\text { all cases shown below except } \\
\text { previous work) }\end{array}$} \\
\hline \multicolumn{3}{|c|}{$\begin{array}{l}\text { Interrogation Window Size } \\
\text { for Final Pass [pixel] }\end{array}$} & $32 \times 32$ & $16 \times 16$ & $12 \times 12$ & $8 \times 8$ \\
\hline \multicolumn{3}{|c|}{ Single Pass Processing } & 0 & 0 & 0 & 0 \\
\hline \multirow{5}{*}{$\begin{array}{c}\text { Recursive } \\
\text { Correlation } \\
\text { Method with } \\
\text { Decreasing } \\
\text { Window Size }\end{array}$} & \multirow{5}{*}{$\begin{array}{c}\text { Number of } \\
\text { Iteration for } \\
\text { Final Interrogation } \\
\text { Window Size } \\
\\
\text { *Bottom row indiates } \\
\text { the interrogation } \\
\text { window size of which } \\
\text { process was } \\
\text { applied once before } \\
\text { main window size }\end{array}$} & 1 & & $\underset{32 \times 32}{\mathrm{O}}$ & & \\
\hline & & 2 & $\begin{array}{c}\text { Previous } \\
\text { work (FFT) } \\
64 \times 64 \\
\end{array}$ & $\underset{32 \times 32}{0}$ & & \\
\hline & & 5 & & $\underset{32 \times 32}{\mathrm{O}}$ & & \\
\hline & & 10 & & $\underset{32 \times 32}{0}$ & & \\
\hline & & 20 & $\underset{64 \times 64}{\bigcirc}$ & $\underset{32 \times 32}{O}$ & $\underset{32 \times 32}{0}$ & $\begin{array}{c}0 \\
16 \times 16\end{array}$ \\
\hline
\end{tabular}

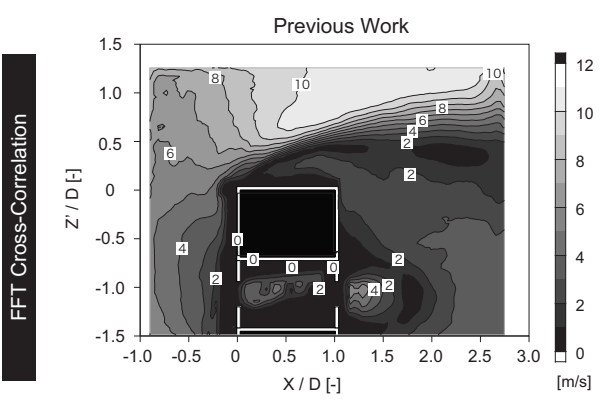

64 pixel $\times 64$ pixel $\times 1$ pass 32 pixel $\times 32$ pixel $\times 2$ pass

Fig. 8 Velocity distribution obtained from PIV in the previous work (only FFT cross-correlation) 
Moving to two results obtained from direct correlation method, velocity distributions are very similar, though the single-pass processing shows spatial variation if compared with recursive processing. On the other hand, comparing velocity distributions from FFT cross-correlation method, the single pass processing results in obviously small velocity, and acceleration due to flow separation is not clear. This is significantly improved by recursive processing procedure. Although this difference is discussed in detail in the following section, it is qualitatively concluded that FFT cross-correlation method should be used with recursive correlation method, because the results can significantly vary depending on the number of recursive processing passes.

\subsection{Velocity and Wind Direction along Horizontal Line of $\mathrm{X}=0 \mathrm{~mm}$}

For more quantitative comparison, average velocity resultant and wind directions obtained from each PIV processing setting are plotted. Fig. 9 gives those results along a line of $\mathrm{X}=0 \mathrm{~mm}$. Here, the results measured by five-hole pitot tube obtained in the previous work are also added, because they are believed to be close to true value ${ }^{* 2}$. As well as Fig. 6, velocity resultant is dimensionless velocity by divided by wind speed of $10 \mathrm{~m} / \mathrm{s}$.

In the cases where the number of recursive passes are changed with interrogation window size of final pass filed to be $16 \times 16$ pixels (left column), smaller velocity is obtained from FFT cross-correlation method as the number of passes is small. The PIV analysis of the previous work (Fig. 6) is conducted with 1 pass with $64 \times 64$ pixels and 2 passes with $32 \times 32$ pixels. This indicates that there was room for improvement regarding processing parameter. On the other hand, when direct cross-correlation method is applied, no significant difference can be seen among all 5 cases of processing pass and these results are similar to those of five-hole pitot tube. Rationale of this difference between FFT and direct cross-correlation method is that FFT cross-correlation method basically uses only the information inside the fixed interrogation window under assumption of periodicity ${ }^{10)}$, whereas interrogation window of the second frame is actually shifted in direct cross-correlation method. The amount of information regarding image intensity in the former becomes fewer than the latter. In the recursive processing procedure of FFT cross-correlation method, location of the interrogation window in the second frame is corrected in the iterative processing based
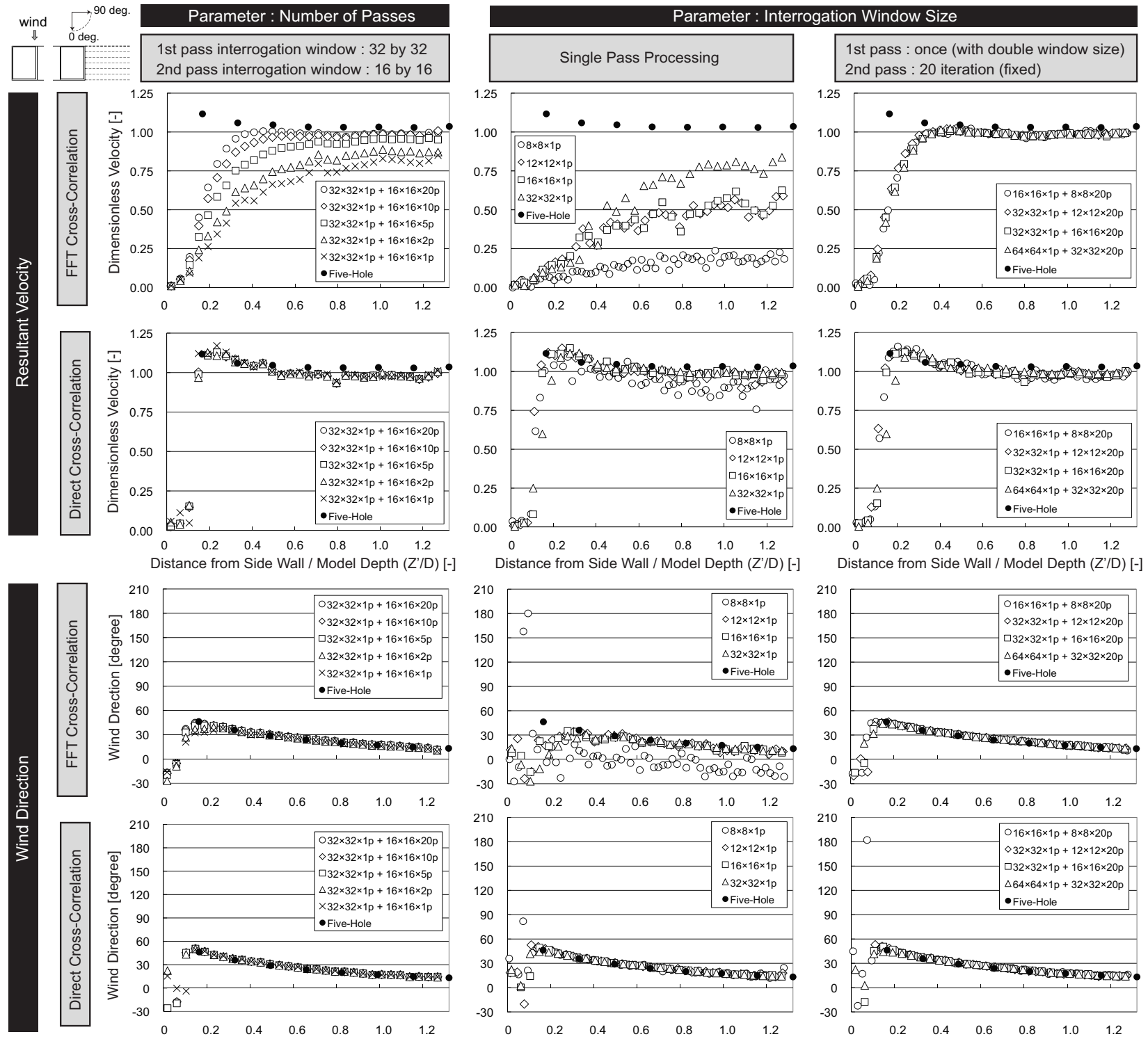

Distance from Side Wall / Model Depth (Z'/D) [-

Distance from Side Wall / Model Depth (Z'/D) [-]

Distance from Side Wall / Model Depth (Z'/D) [-]

Fig. 9 Velocity and Wind Direction obtained from PIV and Five-Hole Pitot Tube along a Line of $X=0 \mathrm{~mm}$ in $Z$ direction 
on the previous processing cycle. This works to correct a peak location of cross-correlation gradually. Thus, it is verified that recursive correlation processing can improve accuracy to some extent.

As for the cases of single pass processing (middle column in Fig. 9), FFT cross-correlation shows much lower velocity than direct cross-correlation and five-hole pitot tube, i.e. when interrogation window size is $8 \times 8$ pixels, less than one-fourth of velocity observed by pitot tube where dimensionless velocity is approximately 1.0, and about three-fourth for $32 \times 32$ pixels. This is obviously due to lack of "effective" information as mentioned above. In this method, calculation of cross-correlation is reduced to complex conjugate multiplication of each corresponding pair of Fourier coefficients as;

$$
\phi_{f g}(m, n)=\mathscr{F}^{-1}\left[\mathscr{F}^{*}\{f(m, n)\} \mathscr{F}\{g(m, n)\}\right]
$$

where, $\phi_{f g}(m, n)$ is discrete cross-correlation of sampled region $f(m, n), g(m, n)$. The cross-correlation is naturally corresponds to its cross spectrum. However, it must be noted that this is valid under an assumption that the same distribution pattern of intensity within the interrogation is repeated cyclically, which is not correct in reality. In other words, only the information of intensity within an analysed interrogation is used in FFT cross-correlation method. The relative amount of tracer flowing out from the interrogation window increases as its size becomes small in FFT cross-correlation method. This naturally gives rise to decrease of accuracy. By contrast, direct correlation method uses information of intensity outside the target interrogation and explores destination by shifting the window actually as;

$$
\phi_{f g}(m, n)=\sum_{k} \sum_{l} f(k, l) \sum_{k} \sum_{l} g(k+m, l+n)
$$

This includes no cyclic assumption, and this is essential difference between two algorithms. That is why direct cross-correlation method can detect location of tracer shift correctly even if single pass is applied for relatively small interrogation window size. Turning back to the single pass processing with $8 \times 8$ pixels by FFT cross-correlation, actual tracer shift seems more than half of interrogation window size because true velocity is almost $10 \mathrm{~m} / \mathrm{s}$ here. Under such a condition of spatial shift, single pass processing of FFT cross-correlation significantly underestimates results because of the cyclic assumption which is not
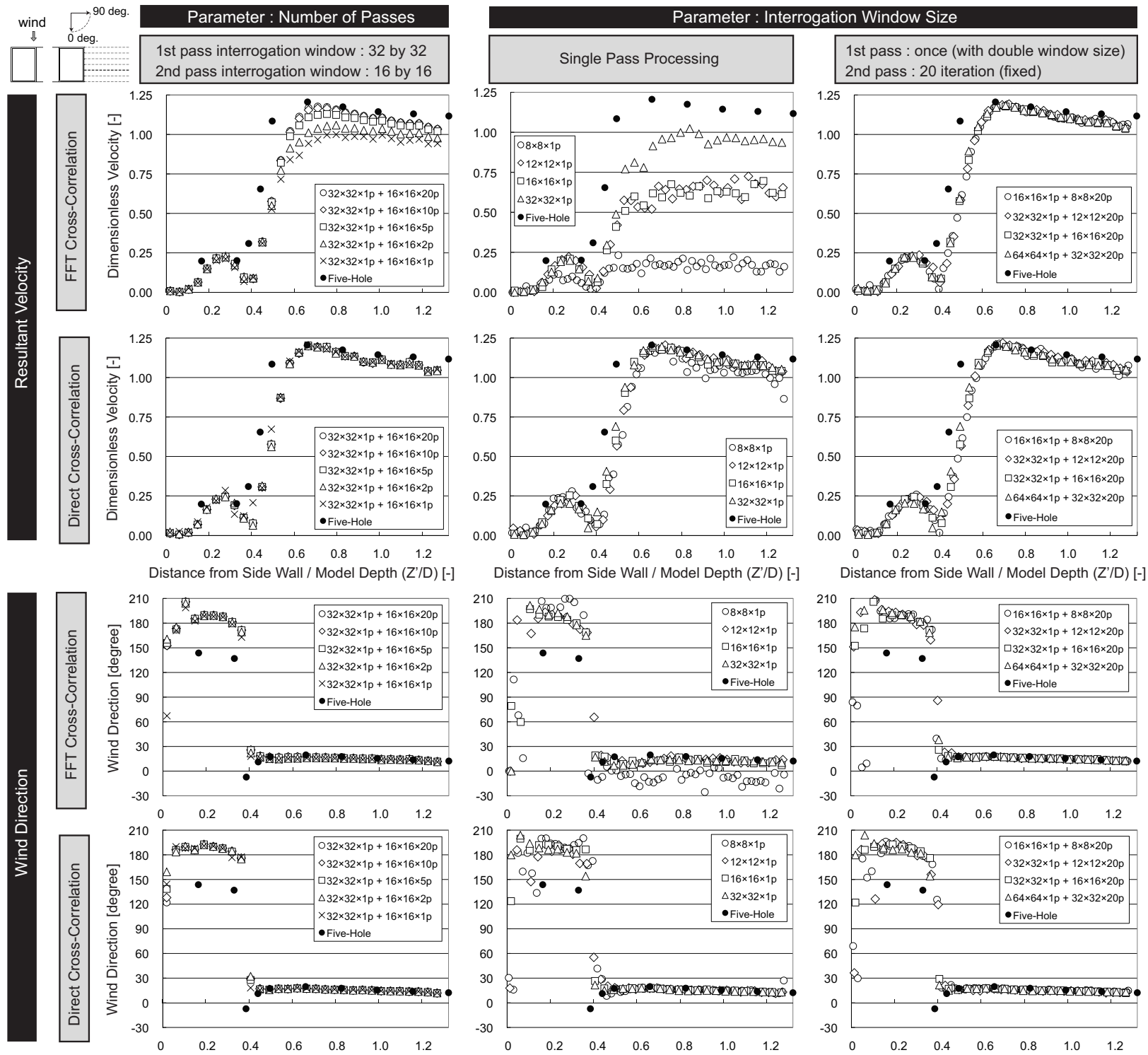

Distance from Side Wall / Model Depth (Z'/D) [-]

Distance from Side Wall / Model Depth (Z'/D) [-]

Distance from Side Wall / Model Depth (Z'/D) [-]

Fig. 10 Velocity and Wind Direction obtained from PIV and Five-Hole Pitot Tube along a Line of $X=120 \mathrm{~mm}$ in $Z$ direction 
correct and tracer pattern is replaced by inflow actually. Even in the case of $32 \times 32$ pixels where spatial shift is relatively small and about $15 \%$ of window length, underestimation of velocity still cannot be negligible. On the other hand, direct cross-correlation method gives rational velocity because interrogation window is actually shifted. This result concludes that FFT cross-correlation method should not be used at least by single pass processing.

Let us move to discussion for effectiveness of recursive processing. In the cases where final pass is fixed at 20 times, difference in velocity distribution due to interrogation window size is not significant in both FFT and direct cross-correlation method. Thus, it is shown that FFT cross-correlation can obtain relatively reliable result by conducting iterative calculation to a certain extent. If compared with direct correlation, however, it is still a little underestimated around separation corner where velocity gradient is large. The reason for this improvement by recursive processing for FFT cross-correlation is simply that the location of interrogation window for the second frame is shifted at every pass based on spatial shift detected in the previous pass.

As for wind direction, all results show almost the same results except the case of single pass processing with FFT cross-correlation method. As mentioned above for velocity resultant, the results of wind direction from FFT-based analysis can also be improved by introducing recursive processing. As a general tendency, wind direction by PIV results in smaller value where Z' is less than $15 \mathrm{~mm}$. Given an actual flow separating from windward facade, wind direction must be close to 90 degrees at the point of $Z^{\prime}=0 \mathrm{~mm}$, and gradually decreased as it is separated from the wall. Although there is no measurement point of five-hole pitot tube nearby the wall, it seems that all PIV results could not detect correct direction where Z' $<15$ mm. This error is understandably caused by captured side wall overlapping on the visualized flow, and this is what cannot be improved by changing the PIV processing parameter.

\subsection{Velocity and Wind Direction along Horizontal Line of $X=120 \mathrm{~mm}$}

In order to evaluate PIV performance under each parameter setting for the flow of different property from the previous section, velocity and wind direction are compared along the horizontal line of $\mathrm{X}=120 \mathrm{~mm}$ in Fig. 10 where wake is included in the measurement line. The results from five-hole pitot tube are also added as well ${ }^{* 3)}$. Here, note that all velocities obtained from five-hole pitot tube are reliable, while the wind direction is more or less underestimated at two points of $Z^{\prime}=30$ and $60 \mathrm{~mm}$ which are assumed to be within wake region as it was discussed in the previous paper ${ }^{16)^{* 4)}}$. As a general tendency, abrupt change is seen around Z'=70 $\mathrm{mm}$ in both results of velocity and wind direction. This indicates the boundary of separation flow. Since there seems to be a wake inside this boundary, back flow should be observed. This corresponds to the results of wind direction approximately 180 degrees in this region.

Focusing on the number of recursive passes (left column in Fig. 10), it does not affect velocity distribution in the cases of direct correlation method, and PIV result well agrees with that of five-hole pitot tube. As for the cases of FFT cross-correlation method, velocity is underestimated when the number of passes is small. Although this tendency was observed along a line of $\mathrm{X}=0 \mathrm{~mm}$ too, there is almost no difference between cases of 10 and 20 passes, i.e. influence of recursive passes is not as large as that in $\mathrm{X}=0 \mathrm{~mm}$. This seems to be due to that velocity gradient across the separation boundary is smaller. Accuracy of PIV regarding wind direction is not affected by the number passes in this comparison, where all cases were analysed through 1 pass of preparatory calculation with double size of interrogation window before the final size. Within the wake region, back flow is well analysed by PIV, while five hole pitot tube underestimates wind direction because of the reason mentioned above.

Comparing PIV results of single pass processing among several cases of interrogation window size (middle column in Fig. 10), direct cross-correlation method generally shows good agreement of velocity with five-hole pitot tube, though $8 \times 8$ pixels showed a little spatial variation to be improved. By contrast, results from FFT cross-correlation method is significantly affected by interrogation window size, of which reason was the same as discussed in the previous section.

By fixing the number of iterative passes at 20 (right column in Fig. 10), all parameter setting resulted in almost the same result. Since relatively large velocity gradient exists around boundary of separation flow, there was a possibility to underestimate velocity because of velocity distribution within a target interrogation window especially in the cases of FFT cross-correlation method. However, the results obtained shows that the effect of interrogation window size became almost negligible by recursive processing despite relatively large velocity gradient around boundary of separation flow. Moreover, each PIV result well agrees with that of five-hole pitot tube which seems to be correctly measured except wind direction at two points of X=30 and 60 mm. At least along this line of $\mathrm{X}=120 \mathrm{~mm}$, therefore, it can be concluded that the accuracy of PIV is satisfactory for a flow field turbulent to this extent, if recursive processing is applied with enough number of passes, and both FFT and direct cross-correlation can work well.

\section{Conclusions}

This paper aims to understand the effect of PIV processing setting on its accuracy in measuring average velocity of turbulent sheer flow field. Based on PIV images for the flow around a cross-ventilated room model obtained in the previous work, a parametric study was performed. Three parameters were mainly studied, that were 1) algorithm to detect cross-correlation peak, i.e. FFT or direct cross-correlation method, 2) difference in accuracy due to recursive processing, and 3) the number processing passes when recursive analysis is applied. By changing these parameters more or less systematically, effect of each parameter was investigated, and conclusions are summarized as follows;

1) FFT cross-correlation method with single pass processing underestimates velocity, especially where velocity gradient is large. By using recursive processing, accuracy can be significantly improved. In this work, the analysis with 20 passes resulted in satisfactory distribution even where velocity gradient is relatively large. 
2) When direct cross-correlation method is applied, even single-pass processing can evaluate velocity adequately as long as spatial shift in detecting peak location is large enough.

3) Recursive processing can also be beneficial to improve spatial variation when direct cross-correlation method is used.

4) The size of interrogation window does not significantly affect PIV result when recursive processing was applied with enough number of passes. If the number of recursive pass is not enough, FFT cross-correlation method underestimates velocity especially in the case of small interrogation window size.

This whole set of knowledge leads to the conclusion that either FFT and direct cross-correlation can work well for highly turbulent flow field, if recursive processing is applied with enough passes. Since there still remains a possibility of underestimation in applying FFT cross-correlation method to extremely turbulent flow, use of direct correlation method with several processing pass is recommended.

\section{Acknowledgement}

The authors are grateful to Ms. Kaori Asai (undergraduate student at that time), Ms. Yasue Tanaka and Mr. Yasuhiro Shiozaki (KANOMAX Japan, respectively) for their help in conducting PIV measurement. A part of this work was supported by Grant-in-Aid for JSPS Fellows (Representative Tomohiro Kobayashi (20-912)), and Grant-in-Aid for Scientific Research (B) (Representative Hisashi Kotani (22360236)) , Japan Society for the Promotion of Science in 2009 and 2010 respectively.

\section{Notes}

*1) Reference velocity of PIV for dimensionless velocity was $8.35 \mathrm{~m} / \mathrm{s}$ in the previous work, which was obtained from a PIV measurement for free flow without the room model, whereas reference velocities for five-hole pitot tube and CFD was $10 \mathrm{~m} / \mathrm{s}$. Provided that there was a possibility that this reference flow was underestimated due to processing parameter setting, all velocity results are normalized by divided by $10 \mathrm{~m} / \mathrm{s}$ throughout this article.

*2) Whereas five-hole pitot tube measure average of 3-D velocity magnitude, PIV result indicates velocity resultant regarding X and Z components. However, this paper compares these velocities assuming Y component of velocity measured by five-hole pitot tube is almost negligible.

*3) Since the effective measurement range of five-hole pitot tube for wind direction was approximately between -75 and 75 degrees, probe was located by 120 degrees in advance at two measurement points of $Z^{\prime}=30$ and $60 \mathrm{~mm}$ so that measurable range for these two points were between 45 and 195 degrees.

*4) This discrepancy of accuracy for velocity and wind direction was caused by that the Angle Factor of this probe was affected by turbulence and pressure distribution in the wake, but Velocity Factor of this probe was not significantly sensitive for error of wind direction (For details, see Kobayashi et al. ${ }^{16)}$ ).

\section{References}

1) Yano M.: Velocity Measurement using Correlation Concerning with Digital Tracer Image, Journal of the Visualization Society of Japan, Volume 3, No. 10, pp.189-192, 1983.7. (In Japanese)

2) Kimura I., Takamori T., and Inoue T.: Image Processing Instrumentation of Flow by Using Correlation Technique - Application to an Unsteady Flow -, Journal of the Visualization Society of Japan, Volume 6, No. 22, pp.269-272, 1986.9. (In Japanese)

3) Kimura I., Takamori T., and Inoue T.: Image Processing Instrumentation of Flow Velocity Vector Distribution by Using Correlation Technique - Application to Vortices in the Wake of a Circular Cylinder -, Transactions of the Society of Instrument and Control Engineers, Volume 23, No. 2, pp.101-107., 1987.2. (In Japanese)

4) Keane R. D. and Adrian R. J.: Theory of cross-correlation analysis of PIV images, Applied Scientific Research, Volume 49, Issue 3, pp. 191-215, 1992.7.

5) Jambunathan K., Ju X. Y., Dobbins B. N. and Ashforth-Frost S.: An Improved Cross Correlation Technique for Particle Image Velocimetry, Measurement Science and Technology, Volume 6, No. 5, pp. 507-514, 1995.5 .

6) Willert C. E. and Gharib M.: Digital Particle Image Velocimetry, Experiments in Fluids, Volume 10, No. 4, pp.181-215, 1991.1.

7) Keane R. D., Adrian R. J, and Zhang Y.: Super-resolution particle imaging velocimetry, Measurement and Science Technology, Volume 6, Number 6, pp. 754-768.

8) Hart D.P. : Super-Resolution PIV by Recursive Local-Correlation, Journal of Visualization, Volume 3, No. 2, pp.187-194, 2000.6.

9) Wieneke B., and Pfeiffer K.: Adaptive PIV with variable interrogation window size and shape, Proceedings of the 15th International Symposium on Application of Laser Techniques to Fluid Mechanics, pp. 1-8, 2010.7.

10) The Visualization Society of Japan (Ed.): Handbook of Particle Image Velocimetry, Morikita Publishing, 2002. (In Japanese)

11) Yamanaka T., Kotani H., and Kato M.: Wind-Induced Ventilation of Room with Single Opening Part 4. Measurement of Airflow Pattern at Single Opening by Particle Image Velocimetry, Summaries of Technical Papers of Annual Meeting of AIJ, D2, pp.666-670, 2002.8. (In Japanese)

12) Zhu S., Kato S., and Yang J. H.: Investigation of Coughed Spit's Transmission Characteristics in a Calm Environment by Subject Experiment and Numerical Analysis, Journal of Environmental Engineering (Transaction of AIJ), No. 586, pp. 25-32, 2004.12. (In Japanese)

13) Nakajima H. Ibaraki K., and Kondo Y.: Study on PIV Analysis Methods for Airflow Supplied from an Air Diffuser, Summaries of Technical Papers of Annual Meeting of AIJ, D2, pp.877-880, 2011.8. (Selected Paper)(In Japanese)

14) Akabayashi S., Sakaguchi J., Tominaga Y., Arinami Y., Takano Y., and Kobayashi K.: Study on the Air flow of Natural Cross Ventilated House in Fluctuating Flow Part 1 Air Flow Visualization and Analysis about Cross Ventilated House Considering Fluctuation of Air Flow by PIV, Summaries of Technical Papers of Annual Meeting of AIJ , D2, pp.807-810, 2014.9. (Selected Paper) (In Japanese)

15) Kobayashi T., Sagara K., Yamanaka T., Kotani H., Takeda S., and Nishimoto N.: Experimental Investigation and Accuracy Study of CFD Analysis for Flow Field around CrossVentilated Building, Journal of Environmental Engineering (Transaction of AIJ), No. 638, pp.481-488, 2009.4. (In Japanese)

16) Kobayashi T., Kotani H., Yamanaka T., Sagara K., Momoi Y., and Asai K.: Wind Tunnel Test and Numerical Simulation for Pressure and Velocity Field around Cross-Ventilated Building, Journal of Environmental Engineering (Transaction of AIJ), No. 662, pp.385-392, 2011.4.

17) Kobayashi T., Sandberg M., Kotani H., and Claesson L.: Experimental Investigation and CFD Analysis of Cross-Ventilation Flow through Single Room Detached House Model, Building and Environment, Volume 45, Issue 12, pp.2723-2734, 2010.12.

18) Kotani H., Yamanaka T., Momoi Y., Sagara K., and Tambara C.: Prediction of Natural and Cross-Ventilation Rate of nLDK-type Housing Unit in Apartment Building Part 2. Measurement of Indoor Air Distribution by means of PIV, Summaries of Technical Papers of Annual Meeting of AIJ, D2, pp.815-818, 2014.9. (Selected Paper) (In Japanese)

19) Kondo Y., and Nakajima H.: Experiments and CFD Simulation on Influence of a Moving Body on Indoor Air Flow, Journal of Environmental Engineering (Transaction of AIJ), Vol. 77, No. 681, pp. 863-871., 2012.11. (In Japanese)

20) Akabayashi S., Oshima T., Arinami Y., Okubo H., Yang X., and Sakaguchi J.: Air flow Measurements in a Scale Model of a Room and Method Selection of Seeding with Tracer Particles, Journal of Environmental Engineering (Transaction of AIJ), Vol. 78, No. 690, pp. 631-638., 2013.8. (In Japanese)

21) Kotani H. and Kobayashi T.: Accuracy Study of PIV Analysis for Flow Field around a Cross-Ventilated Room Model Summaries of Technical Papers of Annual Meeting of AIJ, D2, pp.893-896, 2011.8. (Selected Paper) (In Japanese) 


\section{和文要約}

\section{1.はじめに}

粒子画像流速測定法（PIV）は非接触かつ面的同時測定が可能など の利点を有する測定法であり, 多くの解析アルゴリズムが提案され てきたことで，その技術は飛躍的に向上している。また，FFT 相互 相関法を用いることが一般的であったものが，GPUを使用すること で直接相互相関法を用いることが可能となっており，基礎研究なら びに応用研究での使用例も一般に増加している。PIV は多くの利点を 有する一方で, 結果に誤差を生じる要因も多く存在し, 可視画像の 質と解析手法の 2 通りに大別される。本論文では後者に着目し，代 表的パラメータを組み合わせた精度検証を行う。対象とする気流は 既往の研究で得られた通風時の建物周辺気流とし, 乱流及び剪断気 流の平均速度場を PIV で取得する際に上記パラメータが解析精度に 及ぼす影響を体系的に明らかにすることを目的とする。

\section{2. 既往 PIV 解析の概要}

筆者 ${ }^{15)}$ は既往研究において図 1 に示寸通風室模型を風洞中央に 設置し（図 2), 図 3 に示寸模型中央断面上の周辺気流をPIV により その周辺気流の測定を行った。また，同測定面内で 5 孔ピトー管を 用いた風向・風速の測定と, CFD 解析を行った。PIV の画像取得は 表 1 に示寸設定で行い, PIV 解析は表 2 に示寸通り FFT 相互相関法 を用いて 2 pass の PIV 解析を行うことで, 図 4 に示すように定性的 に流れが良く再現された平均風速の測定結果を得た。解析を行った PIV 画像は図 5(1) に例示寸るもので，瞬時風速に関しても定性的に は自然な流れ場の測定に成功している (図 5(3))。CFD 解析 (LES) と 5 孔ピト一管の風速と比較すると（図 6), X=60,120 mm では傾向 は類似しているもののPIV では風速が過小評価され，X=0 mm では 勾配が大きい箇所においての精度が悪い。このようにPIV の精度の 低下をもたらす要因は, 側壁の見えがかりが測定面と重なることや, トレーサ量が局所的に不十分な箇所があるなどの画像の質も考えら れるが，解析の方法に起因寸る精度低下の可能性も考えられ，次章 では後者に着目して代表的なパラメータを変更した PIV 解析を実施 することで，解析精度に及ぼす影響を把握する。

\section{PIV 解析に関するパラメトリックスタディ \\ 3.1 解析条件}

前章で得られた PIV 画像を用いて，(1) 解析アルゴリズム（FFT/ 直 接相互相関法)，(2)Interrogation Window サイズ，(3) 再帰的相関法の 繰り返し計算数（pass 数）を変更したパラメトリックスタディを実 施する。ここでは全ての条件において FFT 相互相関と直接相互相関 により解析を行うこととし，最終パスにおける Interrogation Window サイズは $8 \times 8,12 \times 12,16 \times 16,32 \times 32$ pixel の 4 条件を設定し た。再帰的相関法を用いる条件では，それぞれの最終パスにおける Interrogation Window に対して 1 辺の長さが 2 倍となる領域における 解析を共通して 1 pass 実施した上で, 再帰回数は最終パスと同様の サイズで $1 ， 2 ， 5 ， 10 ， 20$ pass の 5 条件の検討を行った。また，同 様の Interrogation Window サイズの条件で再帰的相関法を用いずに 1 pass のみの条件（シングル pass）も設定し，これらを組み合わせて 表 3 に示寸計 24 条件の PIV 解析を実施した。

\section{3. $2 \sim 3.4$ 結果と考察}

図 7 に代表的な条件での風速コンターを示す。FFT 相互相関では シングル pass は風速が過小評価され，剥離と縮流による加速も不明 確であるが，再帰的相関法を用いることで大きく改善される傾向に ある。一方, 直接相互相関法では気流が剥離する風上側の模型コー ナー部付近から大きな風速が見られ，シングル pass では空間的なば らつきが若干大きくなるが，定性的にはその違いは大きくない。

模型側方領域の水平ライン $(\mathrm{X}=0 \mathrm{~mm})$ における風速及び風向の PIV 結果を図 9 にまとめて示す。ここでは真值に近いと考えられる 5 孔ピト一管の結果もあわせて表示寸る。FFT 相互相関法では再帰回 数による影響が明確に見られ, pass 数が少ない条件では風速が過小 評価されていたものが，20 passになると一様流部で概ね適切な風速 を算出している。しかし，この条件でも壁面ごく近傍の速度勾配が 極点に大きい箇所で風速を過小評価している。一方，直接相互相関 法では再帰回数が小さい条件でも十分な精度で風速を算出している。 Z'<15 mm の領域では直接相互相関法でも風速を過小に評価している が，模型の見えがかりの影響で画像の質の問題と言え，それ以外の 籄所では解析アルゴリズムと再帰回数のみで風速結果に無視できな い影響が及ぼされると示された。シングル pass 条件では，周期性を 仮定して領域を固定する FFT 相互相関法では interrogation window サ イズの影響が大きく, サイズが小さいと情報量が乏しいために正し い風速が算定されない。一方, 直接相互相関法においては最小步 ズで若干の誤差は見られるが，概して大きな違いは見られない。再 帰回数を 20 回に固定した場合は Interrogation Window サイズの影響 はほとんど見られず，FFT 相互相関，直接相互相関共に概ね良好な 速度分布を示すが，速度勾配が非常に大きい箇所では FFT 相互相 関法は若干勾配を過小評価している。また，風向に関してはシング ル pass の FFT 相互相関法を除いて, 全条件において 5 孔ピト一管と 同様の風向が算定され，信頼し得る結果が得られたと言える。図 10 に示す $\mathrm{X}=120 \mathrm{~mm}$ のラインでも上記の傾向は同様に見られるが，剥 離流と wake の境界付近である程度速度勾配が大きな箇所において, FFT 相互相関法であっても再帰回数が 20 pass の条件では良好な結果 が得られている。また, FFT 相互相関, 直接相互相関のどちらを用 いても, wake 内部の逆流領域は風速・風向共に適切に算定されている。

\section{4. まとめ}

本論文では通風建物周辺の乱流領域及び剪断気流を対象に代表的 なパラメータを組み合わせた PIV 解析を行い，解析精度に及ぼす影 響を明らかにし，その結果以下に示寸知見が得られた。

(1) FFT 相互相関法はシングル pass では風速の過小評価が見られるも のの, 再帰的相関法を導入することで大きく精度の改善が見られ ることが示され, 本研究で対象とした気流場では 20 pass 程度で 概㸚良好な結果が得られた。

(2) 直接相互相関法では探査領域が十分であればシングル pass でも精 度の良い結果が得られた。

(3) 直接相互相関法においても再帰的相関法は平均速度の空間的なば らつきなど局所的な精度の向上に有用である。

(4) 本研究で対象とした程度の速度勾配が見られる箇所であっても, 再帰回数が確保される限り Interrogation Window サイズの影響は 大きくない。

（2015 年 1 月 10 日原稿受理， 2015 年 6 月 1 日採用決定 